\title{
Analysis of the Growth Pattern of Vero Cells Cultured on Dense and Porous Poly (L-Lactic Acid) Scaffolds
}

\author{
Arnaldo Rodrigues Santos Jra*, Samuel Hilsdorf Barbanti ${ }^{\text {b }}$, \\ Eliana Aparecida de Rezende Duek ${ }^{\mathrm{c}}$, Maria Lucia Furlan Wada ${ }^{\mathrm{d}}$ \\ ${ }^{a}$ Center for Human and Natural Sciences, Federal University of ABC, Santo André - SP, Brazil \\ ${ }^{\mathrm{b}}$ Department of Materials Engineering, Faculty of Mechanical Engineering, \\ State University of Campinas, Campinas - SP, Brazil \\ 'Biomaterials Laboratory, Center for Medical and Biological Sciences, \\ Catholic University of São Paulo, Sorocaba - SP, Brazil \\ ${ }^{\mathrm{d}}$ Department of Cell Biology, Institute of Biology, \\ State University at Campinas, Campinas - SP, Brazil
}

Received: September 11, 2008; Revised: June 8, 2009

\begin{abstract}
Poly (L-lactic acid) (PLLA) polymers are the most frequently used substrates for cell culture, tissue regeneration and orthopedic prostheses, mainly because of their atoxic characteristics and good biocompatibility. The objective of this study was to evaluate whether a higher density or different pore diameters (less than $45,180-250$, and $250-350 \mu \mathrm{m}$ ) would change the growth pattern of cultured cells. The cells were found to adhere to and spread over all PLLA scaffolds studied. The cells also showed similar proliferation on dense and porous PLLA scaffolds, except for PLLA scaffolds with a smaller pore diameter. The cytochemical data showed high metabolic cellular activity on the various substrates. Overall, the results indicated satisfactory cell growth and proliferation on the different PLLA scaffolds studied, especially for those with pore diameters of $180-250 \mu \mathrm{m}$ and $250-350 \mu \mathrm{m}$.
\end{abstract}

Keywords: poly (L-lactic acid), scaffolds, cell culture, tissue engineering

\section{Introduction}

Bioresorbable polymers as cell culture substrates play an important role in the development of tissue engineering systems and orthopedic restoration of damaged human body parts. A wide variety of materials have been used in biological systems, with polyesters derived from $\alpha$-hydroxy acids being frequently employed ${ }^{1}$. These applications require specific characteristics of the polymers: the degradation time of the material should be long enough for tissue regeneration to occur, and the morphological characteristics of the material should not have any noxious effects in the patient ${ }^{1,2}$. The bioreabsorbable material most commonly used are poly(L-lactic acid) (PLLA) polymers. PLLA is a polyester used as a cell culture substrate and for the experimental treatment of different types of tissue damage, mainly because of its good biocompatibility ${ }^{3}$. Degradation occurs by hydrolysis, which results in the release of atoxic degradation monomers that are eliminated from the organism through metabolic processes, such as the citric acid cycle, or by direct renal excretion ${ }^{1,2}$. Different PLLA scaffolds are frequently used as cell culture substrates ${ }^{4,5}$ and for the experimental treatment of damaged animal tissues such as cartilage $\mathrm{e}^{6,7}$ and bone ${ }^{8}$.

In the field of tissue engineering, the use of biomaterials as cell substrates is fundamental for the reconstruction of organs and tissues. Numerous materials can be used as scaffolds, but temporary scaffolds are of special interest since support should be present during tissue repair in order to promote guided tissue growth. Among the various characteristics of bioresorbable materials, porous morphology is important because the presence of pores permits cell penetration and tissue ingrowth 9 . The objective of the present study was to evaluate how variations in the pore diameter of PLLA scaffolds changes the growth and proliferation pattern of cells cultured on these scaffolds. These parameters are important for the evaluation of the interaction between cells and biomaterials in order to predict the integration of the polymer in the target tissue once it has been implanted in vivo.

\section{Material and Methods}

\subsection{Preparation of dense and porous PLLA scaffolds}

Dense PLLA scaffolds were prepared by dissolving PLLA $(\mathrm{Mw}=300,000 ;$ Medisorb Technologies, Cincinnati, OH, USA) at room temperature in $10 \%$ chloroform (w/v) (Merck, Darmstadt, Germany). The scaffolds were dried by casting in a closed chamber connected to a compressed dry-air source $\left(0.01 \mathrm{~nm}^{3} / \mathrm{h}\right)$ for 24 hours. The porous PLLA scaffolds were prepared by dissolving PLLA in $10 \%$ chloroform (w/v) at room temperature. In addition, $40 \mathrm{~g}$ sieved sodium citrate particles (Fluka Cheme, Burchs, Switzerland) with grain diameters $<45,180-250$ and $250-350 \mu \mathrm{m}$ were added in portions of $10 \mathrm{~g}$ to $70 \mathrm{ml}$ of the PLLA-chloroform solution in order to obtain a film with a pore volume of approximately $80 \%$. The drying procedure was the same as that described for non-porous film. After drying, the film was washed in demineralized water for 24 hours 
to remove the salt and then in ethanol for 6 hours. Both polymers were vacuum dried and kept in a desiccator for 5 days to guarantee complete removal of the solvent.

\subsection{Characterization of the PLLA scaffolds}

To morphologically characterize the substrates, the PLLA scaffolds were fractured by immersion in liquid nitrogen, coated with gold in a sputter coater (Baltec SCD 050), and examined under a JEOL ${ }^{\circledR}$ JXA-840A (Jeol ${ }^{\circledR}$ Co., Tokyo, Japan) scanning electron microscope.

\subsection{Cell cultures}

After sterilization, the PLLA scaffolds were washed three times in Ham F-10 medium (Sigma, St. Louis, MO, USA) and then incubated in the same medium for 24 hours at $37{ }^{\circ} \mathrm{C}$ before cell inoculation. Vero cells, a fibroblast lineage were used. These cells were cultured in Ham F-10 medium with $10 \%$ fetal calf serum (FCS; Nutricell, Campinas, SP, Brazil) at $37{ }^{\circ} \mathrm{C}$. Vero cells have been recommended for cytotoxicity studies and for the analysis of cell-substrate interactions in biomaterial research ${ }^{10,11}$.

\subsection{Cell growth on the substrates}

Proliferation was assayed using the method described by Mosmann ${ }^{12}$. A $200-\mu 1$ aliquot of a cell suspension $\left(1.0 \times 10^{4}\right.$ cells $\left./ \mathrm{mL}\right)$ was inoculated onto the different PLLA scaffolds $(n=9)$ in a 96-well culture plate (Corning, Cambridge, MA, USA). The cells were cultured at $37{ }^{\circ} \mathrm{C}$ for $48,120,240$ and 360 hours, and then washed twice with $0.1 \mathrm{M}$ phosphate buffered saline (PBS), $\mathrm{pH}$ 7.4. Next, $100 \mu \mathrm{L}$ medium without FCS containing $10 \mu \mathrm{L}$ 3-(4,5-dimethylthiazol-2-yl)-2,5-diphenyl tetrazolium bromide (MTT, Sigma) was added. After 4 hours, $100 \mu \mathrm{L}$ isopropanol acid (Isofar ${ }^{\circledR}$ Ind. Produtos Químicos, Jacaré, RJ, Brazil) was added. The plates were read in a Multiskan Bichromatic Version 1.06 microplate reader (Labsystems Inc., Helsinki, Finland) at a wavelength of $540 \mathrm{~nm}$. The culture plate itself (polypropylene) was used as positive control, and silicone scaffolds served as negative controls. Absorbance measurements obtained for all experimental conditions (dense and porous PLLA, negative and positive controls) in the absence of cells were used as control of the MTT reaction.

\subsection{Scanning electron microscopy}

For analysis of cell morphology, $1.0 \times 10^{5}$ cells $/ \mathrm{ml}$ were inoculated onto dense and porous scaffolds in 24-well culture plates (Corning) in Ham F-10 medium supplemented with 10\% FCS. Cells cultured on glass coverslips under the same conditions were used as control. After 24 hours of incubation, the samples were fixed in $3 \%$ glutaraldehyde (Sigma) in $0.1 \mathrm{M}$ phosphate buffer, $\mathrm{pH} 7.2$, for 45 minutes at $4{ }^{\circ} \mathrm{C}$, and postfixed in $1 \% \mathrm{OsO}_{4}$ (Sigma) for 2 hours at $4{ }^{\circ} \mathrm{C}$. The specimens were then dehydrated in a graded ethanol series, critical-point dried (Balzers CDT 030, Balzers ${ }^{\circledR}$ Inc., Elgin, IL, USA), and coated with gold in a sputter coater. The coated specimens were observed and photographed under a JEOL ${ }^{\circledR}$ JSM-5800 scanning electron microscope.

\subsection{Cytochemical analysis}

For cytochemical analysis, $1.0 \times 10^{5}$ cells $/ \mathrm{mL}$ were cultured on the different PLLA scaffolds for 120 and 240 hours in Ham F-10 medium supplemented with $10 \%$ FCS at $37{ }^{\circ} \mathrm{C}$. After incubation, the samples were fixed with Karnovsky's fixative (4\% paraformaldehyde $2.5 \%$ glutaraldehyde in $0.2 \mathrm{M}$ phosphate buffer, $\mathrm{pH} 7.2$ ), dehydrated in a graded ethanol series at room temperature, cleared in xylene, and embedded in paraplast. Sections of $5 \mu \mathrm{m}$ were cut with a microtome
(Reicher-Jung, NY, USA) using a steel knife (Leica Instruments, Nussloch, Germany). The cultures were then stained with Toluidine blue (TB), $\mathrm{pH}$ 4.0, a basophilic dye, for the detection of DNA, RNA and glycosaminoglycans. The cultures were also stained with Alcian blue (AB), pH 2.5, a basophilic dye, for the detection of glycosaminoglycans and, finally, with Xylidine ponceau (XP), $\mathrm{pH} 2.5$, an anionic dye, for the identification of cationic proteins ${ }^{13-15}$. The coverslips were photographed under an inverted IX-50 Olympus ${ }^{\circledR}$ microscope (Tokyo, Japan).

\section{Results and Discussion}

Intense searches for better biomaterials have led to a growing number of clinical applications of bioresorbable polymers ${ }^{1-3}$. This knowledge has permitted the use of biomaterials for cell culture techniques to create tissue-like structures that simulate the mechanical and physiological characteristics of tissues, manipulating the healing process and stimulating natural tissue regeneration.

\subsection{Characterization of the PLLA scaffolds}

Morphological analysis of the PLLA scaffolds showed that all substrates with a thickness of about $0.3 \mathrm{~mm}$ had a smooth and regular lower surface due to the preparation procedure. We did not find significant variations in membrane thickness. The dense PLLA membranes presented an irregular and rough upper surface, but fracture analysis confirmed that the material was compacted. As expected, the porous scaffolds showed variations in pore diameter. Fracture analysis also showed homogeneous pore distribution and pore interconnections (Figure 1).

The morphology of the PLLA scaffolds was as expected ${ }^{5,16,17}$. Porous PLLA scaffolds have been produced in different manners, for example, by adding salt ${ }^{5,16,17}$ or by immersion precipitation processes $^{18}$. Although the presence of pores in biomaterials is a desired condition, production costs play an important role. Thus, different types of fabrication of porous materials have been tested in order to reduce costs and to make biomaterial technology and tissue engineering available to more patients.

\subsection{Morphology of cells cultured on dense and porous PLLA scaffolds}

Scanning electron microscopy demonstrated the formation of confluent cell layers on the glass coverslips. These cells had an irregular morphology, sometimes presenting microvilli and/or cell prolongations on their surface (Figure 2a). Cells cultured on dense PLLA membranes showed a morphology similar to those grown on control glass coverslips, with these cells presenting a large number of microvilli and/or vesicles on their surface (Figure 2b). Flattened cells were observed on the surface of the $45-\mu \mathrm{m}$ pore PLLA scaffolds (Figure 2c). Cells cultured on the 180-250 $\mu \mathrm{m}$ pore PLLA scaffolds presented an irregular morphology and numerous prolongations. These prolongations often formed thin reticulate fibrils on the cell surface (Figure $2 \mathrm{~d}$ ). The cells cultured on the $250-350 \mu \mathrm{m}$ pore PLLA scaffolds were flattened and presented numerous microvilli and/or vesicles on their surface (Figure 2e).

The cells cultured on the different substrates presented different morphological patterns. The cells grown on the PLLA scaffolds showed cell processes that were sometimes similar to one another, and a large number of microvilli on the cell surface. Similar results have been reported previously for Vero cells cultured on PLLA scaffolds ${ }^{19,20}$. Alterations in cell morphology are related to the organization of cytoskeletal networks. The topography of polymers and the rigidity/flexibility of their surface have been reported to be related to cell migration and the functional activity of the cytoskeleton ${ }^{21}$. In 


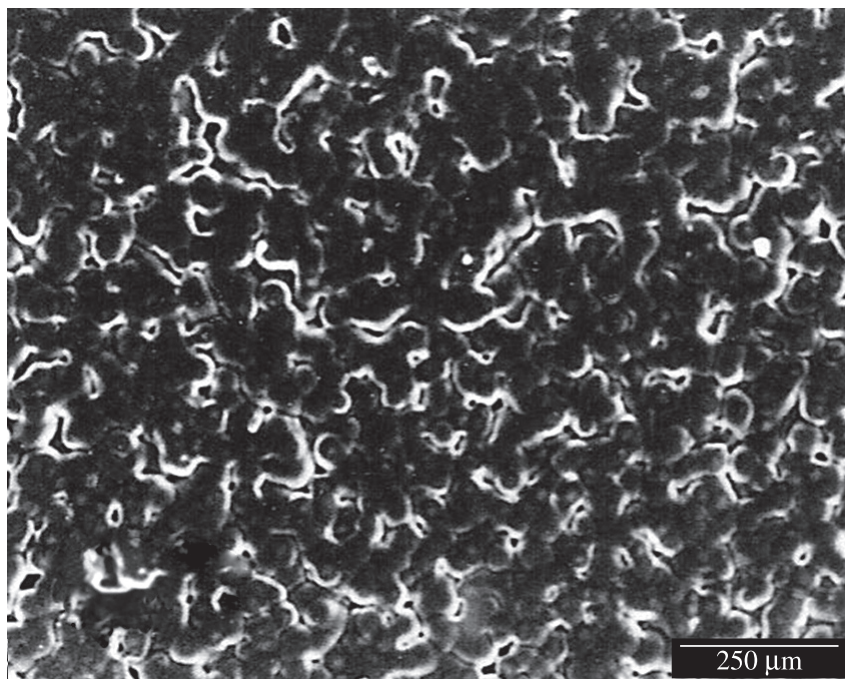

(a)

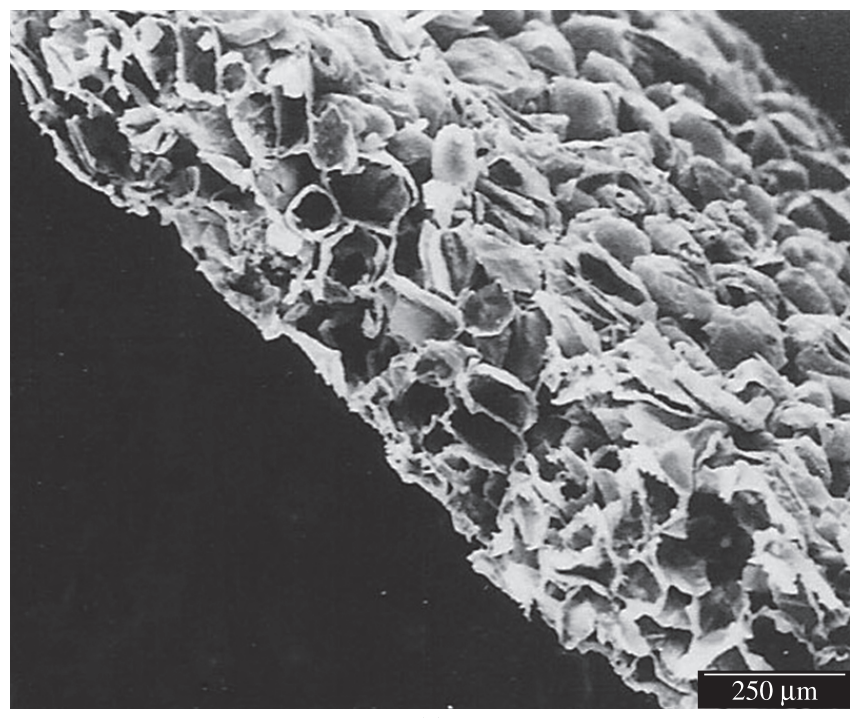

(c)

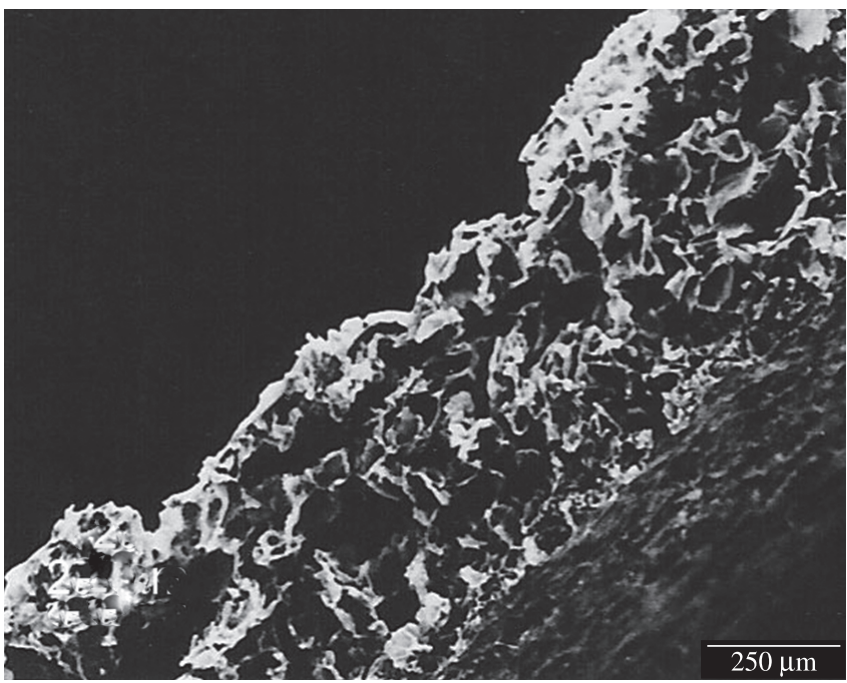

(b)

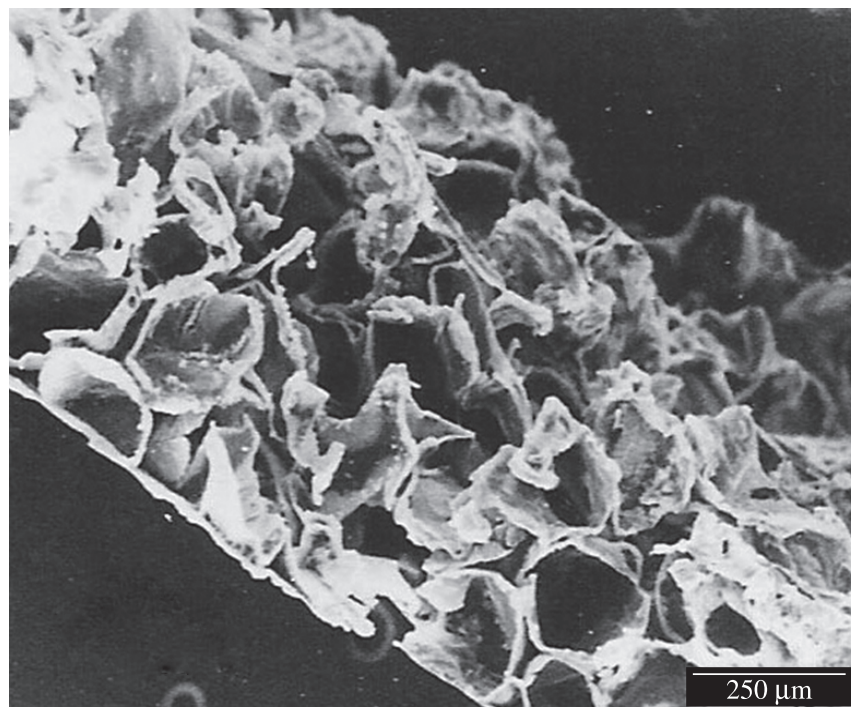

(d)

Figure 1. Scanning electron microscopy of PLLA membranes. a) Dense PLLA membrane, b) PLLA membrane with a pore diameter less than $45 \mu \mathrm{m}$, c) PLLA membrane with a pore diameter of 180-250 $\mu \mathrm{m}$, and d) PLLA membrane with a pore diameter of 250-350 $\mu \mathrm{m}$.

the present study, the cells cultured on the PLLA scaffolds tested were able to form a confluent monocellular layer, but did not grow in multicellular layers. This behavior is similar to the pattern of normal growth observed for non-biological surfaces, such as glass coverslips, but differs from the growth patterns seen on biological substrates such as three-dimensional type I collagen substrates ${ }^{22,23}$. The interaction between cells and the biomaterial should permit cell adhesion and spreading. Several studies have shown a clear distinction between materials that support cell adhesion and those that do not. The inability of certain materials to support cell adhesion/spreading facilitates the detection of changes in cell adhesion induced by surface modification, for example, surface coating. This fact can be used to better understand surface properties that are able to stimulate cell adhesion and the subsequent spreading and growth of cells ${ }^{24}$

\subsection{Growth curve}

The MTT assay was used for the evaluation of cell growth. MTT is a colorless tetrazolium salt that, when oxidized in the mitochondria, forms a dark compound detectable by spectrophotometry. The result is proportional to the number of cells. The MTA assay permitted the observation of cell proliferation on all polymeric substrates tested. No differences in the proliferation rate were observed between the different PLLA scaffolds, except for the membrane with the smaller pore diameter (Figure 3).

Studies have shown that porous materials are able to stimulate cell proliferation and that the uniformity of the distribution and interconnectivity of the pores are important to facilitate tissue formation in an organized network in vivo ${ }^{2,3}$. There was no stratification of cells grown on the different substrates. These data suggest that PLLA does not induce any loss of contact-induced/density-dependent inhibition of cell growth. The pore diameter of less than $45 \mu \mathrm{m}$ presents almost the same size as the cells occupying the pore, with the space for cell proliferation thus being limited. This might explain the low mitotic rate observed for cells grown on the small-pore diameter scaffolds. Thus, the $45-\mu \mathrm{m}$ pore diameter PLLA membrane may not be suitable for cell culture research or tissue engineering experiments. 


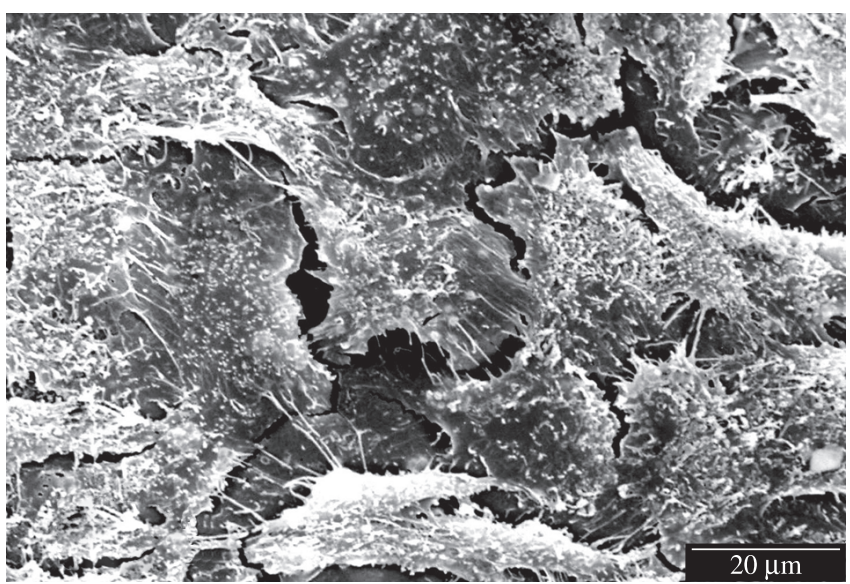

(a)

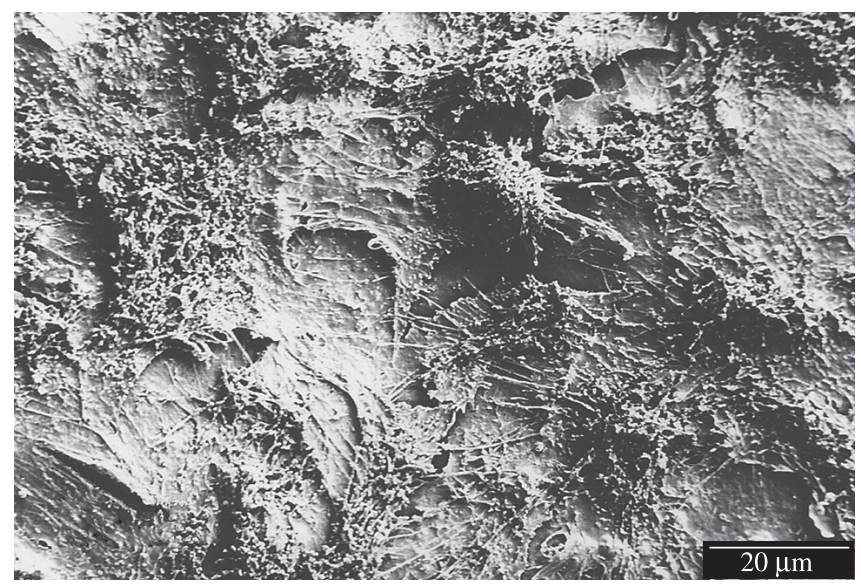

(b)

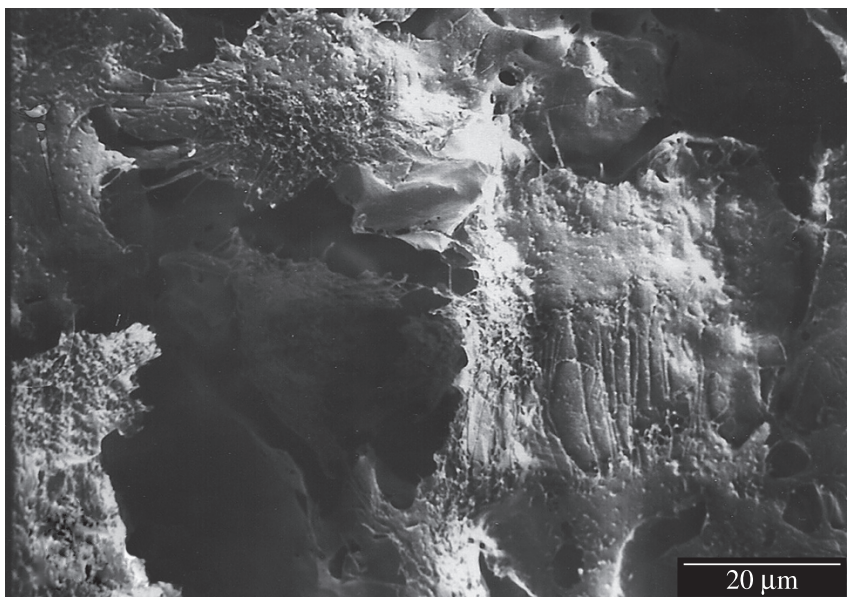

(c)

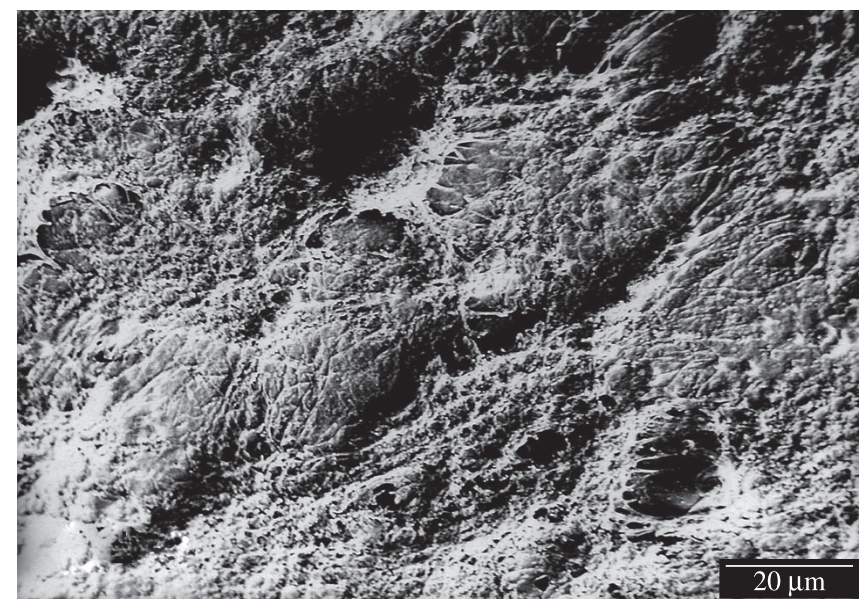

(d)

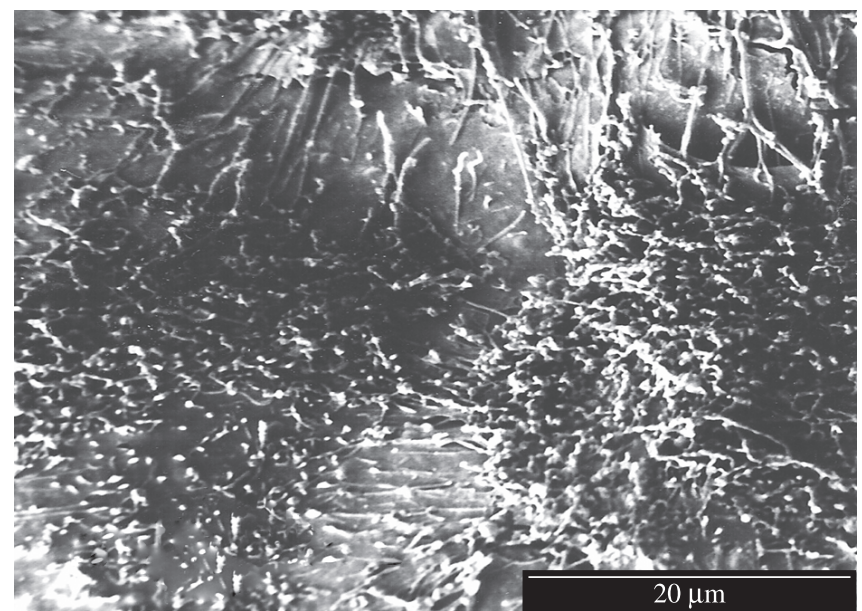

(e)

Figure 2. Scanning electron microscopy of Vero cells cultured on different poly(L-lactic acid) membranes for 24 hours. a) Cells grown on a glass coverslip, b) cells grown on a dense membrane (note the cell processes linking the cells to one another), c) cells cultured on a membrane with a pore diameter less than $45 \mu \mathrm{m}, \mathrm{d}$ ) cells cultured on a membrane with a pore diameter of $150-250 \mu \mathrm{m}$, and e) cells cultured on a membrane with a pore diameter of $250-350 \mu \mathrm{m}$. 


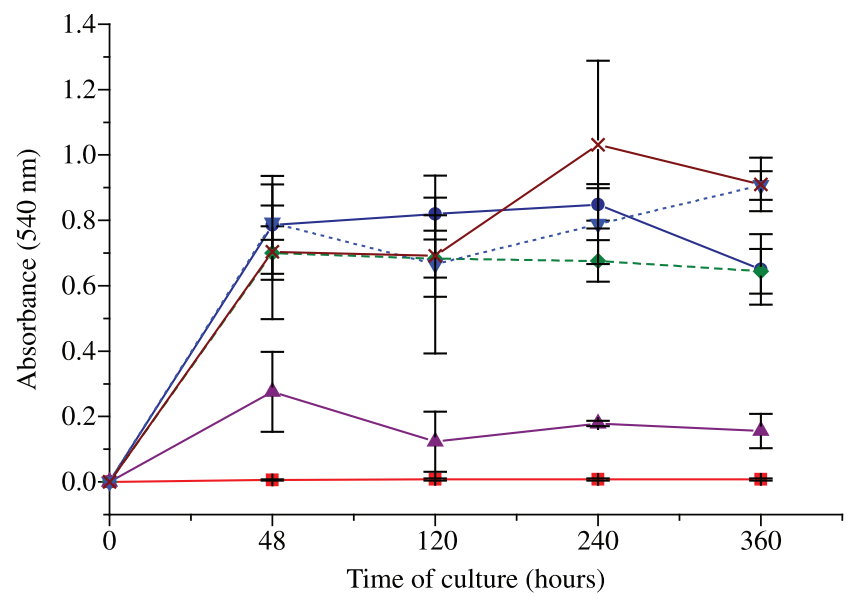

$$
\begin{array}{|ll|}
\hline-\square-\text { Negative control } & -\bigcirc-\text { Positive control } \\
-- \text { - PLLA dense } & -\Delta-\text { PLLA p. }<45 \mathrm{um} \\
-\boldsymbol{-} \text { - - PLLA p. } 180-250 \mathrm{um} & -\mathrm{X}-\text { PLLA p. } 250-350 \mathrm{um} \\
\hline
\end{array}
$$

Figure 3. Growth curve of Vero cells cultured on dense or porous PLLA membranes.

Toluidine blue (pH 4.0)

120 hours

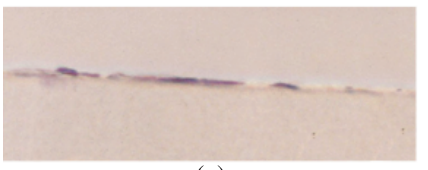

(a)

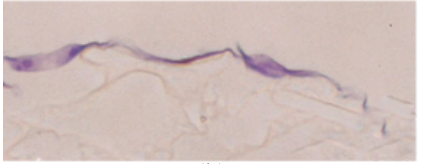

(b)

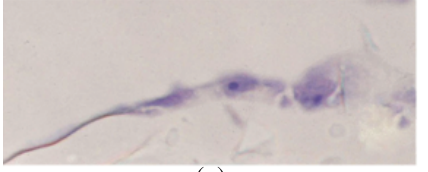

(c)

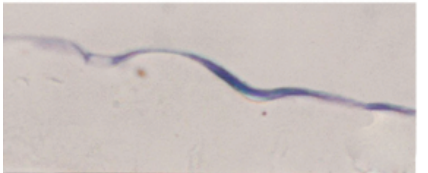

(d)

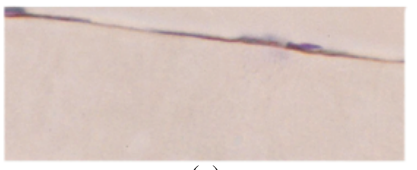

(e)

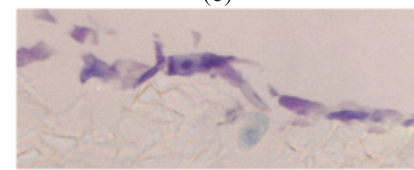

(f)

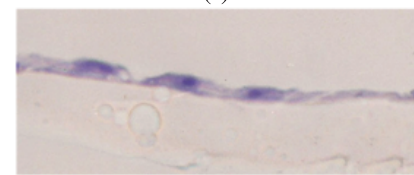

(g)

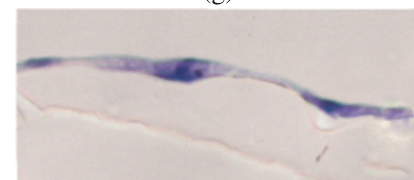

(h)

Xylidine ponceau ( $\mathrm{pH}$ 2.5)

120 hours

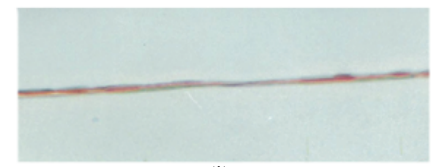

(i)

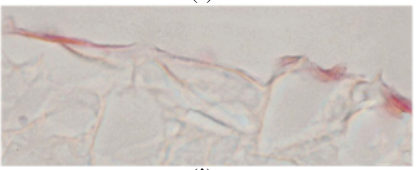

(j)

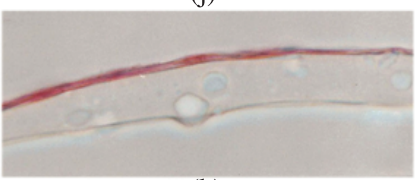

(k)

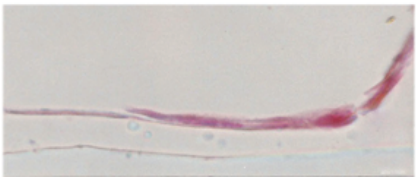

(1)
240 hours

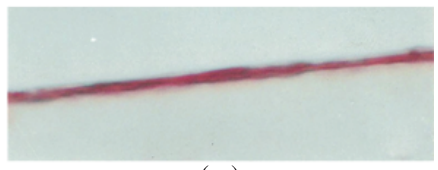

(m)

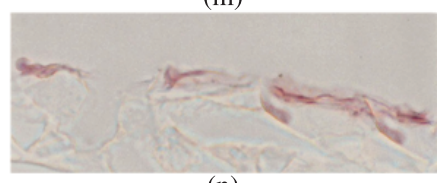

(n)

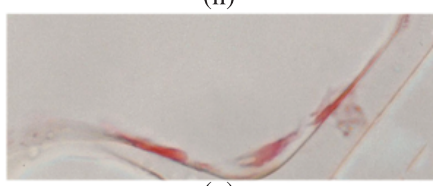

(o)

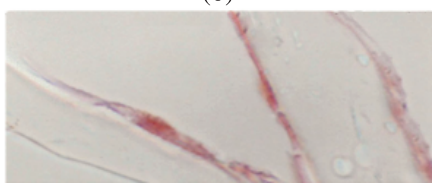

(p)

Figure 4. Cytochemical analysis of cells cultured on different PLLA membranes. Cells cultured on a dense PLLA membrane for 120 hours (a and i) and 240 hours (e and m). Cells cultured on a PLLA membrane with a pore diameter less than $45 \mu \mathrm{m}$ for 120 hours (b and j) and 240 hours (f and $\mathrm{n}$ ). Cells cultured on a PLLA membrane with a pore diameter of $180-250 \mu \mathrm{m}$ for 120 hours ( $\mathrm{c}$ and $\mathrm{k}$ ) and 240 hours ( $\mathrm{g}$ and $\mathrm{o}$ ). Cells cultured on a PLLA membrane with a pore diameter of 250-350 $\mu \mathrm{m}$ for 120 hours ( $\mathrm{d}$ and $\mathrm{l}$ ) and 240 hours (h and p). From a) to h), samples were stained with Toluidine blue, $\mathrm{pH} 4.0$, and from i) to p) samples were stained with Xylidine ponceau, $\mathrm{pH} 2.5$.

PLLA scaffolds have been used as substrates for the growth and proliferation of different cell types, such as endothelial ${ }^{25,26}$ and osteogenic $^{27}$ cells. The ability of polymers to stimulate cell growth and proliferation might be related to protein adsorption on the material surface. One interesting experiment showed that the introduction of free amino groups on the surface of the PLLA substrate improves the spreading and proliferation of human endothelial cells on polymer surfaces ${ }^{26}$. Furthermore, extracellular matrix proteins such as fibronectin, laminin and collagen have been reported to improve cell multiplication on bioreabsorbable scaffolds ${ }^{28}$. In a previous study, we showed that Vero cells produce fibronectin and collagen IV when cultured on dense and porous PLLA scaffolds ${ }^{19}$ or PLLA blended with other bioreabsorbable polyesters such as poly(hydroxylbutyrate-cohydroxyvalerate) (PHBV) ${ }^{29}$. In this respect, the results of Vero cell multiplication on PLLA scaffolds is compatible with those reported for PLLA/PHBV blends in another study ${ }^{20}$. Extracellular matrix production is probably related to the positive proliferation pattern 
observed on the substrates tested. Thus, the present PLLA scaffolds showed a satisfactory capacity to maintain cell proliferation similar to that reported by other investigators.

\subsection{Cytochemical analysis}

The cells grew until confluence and then entered the pores, creating three-dimensional arrangements. Cytochemical analysis using TB revealed the presence of basophilic cell monolayers. No AB staining was observed in any of the samples studied (data not shown). Staining with XP revealed high acidophilia (Figure 4). The different PLLA scaffolds tested induced no cytochemical alterations in the cells.

Cytochemistry revealed no changes in cell behavior induced by dense or porous PLLA scaffolds. TB-stained basophilic cells were observed in all samples. At pH 4.0, TB stains nucleic acids and glycosaminoglycans. Although Vero cells synthesize glycosaminoglycans ${ }^{30}$, they produce them in soluble form in the culture medium. Thus, the presence of basophilic cytoplasm suggests that the cells are able to carry out active protein synthesis. The fact that XP stains protein groups confirms these results. A similar cytochemical pattern has been observed for Vero cells cultured on other biomaterials such as poly-HEMA hydrogels ${ }^{31,32}$ and PLLA/PHBV blends ${ }^{20}$.

\section{Conclusions}

Similar results were obtained for all PLLA scaffolds tested in this study, except for those with a pore diameter smaller than $45 \mu \mathrm{m}$. Since porous membranes are more indicated for in vivo restoration of damaged tissues, the PLLA scaffolds with pore diameters of $180-250 \mu \mathrm{m}$ and $250-350 \mu \mathrm{m}$ showed the best results as cell culture substrates. Further studies are necessary to evaluate the potential of these scaffolds in clinical tissue engineering applications.

\section{Acknowledgements}

This study was supported by the National Council for Scientific and Technological Development (CNPq).

\section{References}

1. Ambrose CG and Clanton TO. Bioabsorbable implants: review of clinical experience in orthopedic surgery. Annals of Biomedical Engineering. 2004; 32(1): 171-177.

2. An YH, Woolf SK and Friedman RJ. Pre-clinical in vivo evaluation of orthopedic bioabsorbable devices. Biomaterials. 2000; 21(24): 2635-2652.

3. Santos Jr AR and Wada MLF. Polímeros biorreabsorvíveis como arcabouços para cultura de células e engenharia tecidual. PolímerosCiência e Tecnologia. 2007; 17(4): 308-317.

4. Wald HL, Sarakinos G, Lyman MD, Mikos AG, Vacanti JP and Langer R Cell seeding in porous transplantation devices. Biomaterials. 1993; 14(4): 270-278

5. Barbanti SH, Santos Jr AR, Zavaglia CAC and Duek EAR. Porous and dense poly(L-lactic acid) and poly(D,L-lactic acid-co-glycolic acid) scaffolds: In vitro degradation in culture medium and osteoblasts culture. Journal of Material Science: Materials in Medicine. 2004; 15(12): 1315-1321.

6. Freed LE, Marquis JC, Nohria LE, Emmanual J, Mikos AG and Langer R. Neocartilage formation in vitro and in vivo using cell cultures on synthetic biodegradable polymers. Journal of Biomedical Material Research. 1993; 27(1): 11-23.

7. Temenoff JS and Mikos AG. Review: tissue engineering for regeneration of articular cartilage. Biomaterials. 2000; 21(5): 431-440.
8. Ishaug-Riley SL, Crane-Kruger GM, Yaszemski MJ and Mikos AG. Threedimensional culture of rat calvarial osteoblasts in porous biodegradable polymers. Biomaterials. 1998; 19(15): 1405-1412.

9. Barbanti SH, Zavaglia CAC and Duek EAR. Effect of salt leaching on PCL and PLGA(50/50) resorbable scaffolds. Materials Research. 2008: 11(1): 75-80.

10. ISO 10993-5:1992(E). Biological evaluation of medical devices - Part5 - tests for cytotoxicity: in vitro methods. Geneva; 1992.

11. Kirkpatrick CJ. Biological testing of materials and medical devices - A critical view of current and proposed methodologies for biocompatibility testing: cytotoxicity in vitro. Regulatory Affairs. 1992; 4(1): 13-32.

12. Mosmann T. A rapid colorimetric assay of cellular growth and survival: application to proliferation and cytotoxicity assays. Journal of Immunological Methods. 1983; 65(1-2): 55-63.

13. Lison L. Histochemie et Cytochemie Animales - Principles et Methodes. Paris: Gauthier Villars; 1960.

14. Módis L. Organization of the Extracellular Matrix - A Polarization Microscopic Approach. Boca Raton: CRC Press; 1991.

15. Mello MLS. Cytochemistry of DNA, RNA and nuclear proteins. Brazilian Journal of Genetics. 1997; 20(2): 257-264.

16. Barbanti SH, Zavaglia CAC and Duek EAR. Porous and dense poly (L-lactic acid) membranes: in vitro degradation. Acta Microscopica. 2002; 11(1): 85-89.

17. Barbanti SH, Zavaglia CAC, Santos Jr AR and Duek EAR. Poly(L-lactic acid) scaffold: in vitro degradation in alkaline medium, phosphate buffer solution and osteoblast morphology. Revista CENIC-Ciências Biológicas. 2006; 37(3): 182-187.

18. Zoppi RA, Contant S, Duek EAR, Marques FR, Wada MLF and Nunes SP. Porous poly(L-lactide) films obtained by immersion precipitation process: morphology, phase separation and culture of VERO cells. Polymer. 1999; 40(12): 3275-3289.

19. Santos Jr AR, Barbanti SH, Duek EAR, Dolder H, Wada RS and Wada MLF. Growth and differentiation of Vero cells on poly(L-lactic acid) membranes of different pore diameters. Artificial Organs. 2001; 25(1): $7-13$.

20. Santos Jr AR, Ferreira BMP, Duek EAR, Dolder H and Wada MLF. Use of blend of bioabsorbable poly(L-lactic acid)/poly(hydroxybutyrate-cohydroxyvalerate) as surface for Vero cell cultured. Brazilian Journal of Medical and Biological Research. 2005; 38(11): 1623-1632.

21. Pelham RJ and Wang YL. Cell locomotion and focal adhesion are regulated by substrate flexibility. Proceedings of National Academic Science of the USA. 1997; 94(25):13661-13665.

22. Santos Jr AR, Dolder H and Wada MLF. Effects of fetal calf serum and dexamethasone in the differentiation of fibroblastic cells cultured on collagen I gel. Journal of Submicroscopical Cytology and Pathology. 2003; 35(1): 35-42.

23. Moreira P, An YH, Santos Jr AR and Genari SC. In vitro analysis of anionic collagen scaffolds for bone repair. Journal of Biomedical Materials Research. 2004; 71B(2): 229-237.

24. Lucchesi C, Ferreira BMP, Duek EAR, Santos Jr AR and Joazeiro PP. Increased response of Vero cells to PHBV matrices treated by plasma. Journal of Materials Science: Materials in Medicine. 2008; 19(2): 635-643.

25. Hsu SH, Tseng HJ and Fang ZH. Polyurethane blended with polylactides for improved cell adhesion and reduced platelet activation. Artificial Organs. 1999; 23(10): 958-961.

26. Zhu YB, Gao CY, Liu XY, He T and Shen JC. Immobilization of biomacromolecules onto aminolyzed poly(L-lactic acid) toward acceleration of endothelium regeneration. Tissue Engineering. 2004; 10(1-2): 53-61.

27. Zhou DL, Yang WZ, Yin GF, Zheng CQ, Zhang Y, Chen HQ and Chen $\mathrm{R}$. In vitro characterizations of PLLA-beta-TCP porous matrix materials and RMSC-PLLA-beta-TCP composite scaffolds. Journal of Materials Science and Technology. 2004; 20(3): 248-252. 
28. Aframian DJ, Cukierman E, Nikolovski J, Mooney DJ, Yamada KM and Baum BJ. The growth and morphological behavior of salivary epithelial cells on matrix protein-coated biodegradable substrata. Tissue Engineering. 2000; 6(3): 209-216.

29. Santos Jr AR, Ferreira BMP, Duek EAR, Dolder H, Wada RS and Wada MLF. Differentiation pattern of Vero Cells Cultured on Poly(L-Lactic Acid)/Poly(Hydroxybutyrate-co-Hydroxyvalerate) Blends. Artificial Organs. 2004; 28(4): 381-389.

30. Stabellini G, Calastrini C, Scapoli L, Locci P, De Mattei M, Dellavia C, Moscheni C, Vertemati M and Bedani PL. The effect of polyamines and dialysate fluid on extracellular matrix synthesis in VERO cell cultures. Journal of Nephrology. 2002; 15(5): 539-546.

31. Lombello CB, Malmonge SM and Wada MLF. Morphology of fibroblastic cells cultured on poly(HEMA-co-AA) substrates. Cytobios. 2000a; 101(397): 115-122.

32. Lombello CB, Malmonge SM and Wada MLF. PolyHEMA and polyHEMA-poly(MMA-co-AA) as substrates for culturing Vero cells. Journal of Material Science Materials in Medicine. 2000b; 11(9): 541-546. 